\title{
Author Correction: DNA methyltransferase DNMT3a contributes to neuropathic pain by repressing Kcna2 in primary afferent neurons
}

Jian-Yuan Zhao, Lingli Liang, Xiyao Gu, Zhisong Li, Shaogen Wu, Linlin Sun, Fidelis E. Atianjoh, Jian Feng, Kai Mo, Shushan Jia, Brianna Marie Lutz, Alex Bekker, Eric J. Nestler \& Yuan-Xiang Tao

Correction to: Nature Communications https://doi.org/10.1038/ncomms14712, published online 8 March 2017.

The original version of this article contained an error in the author affiliations. Yuan-Xiang Tao was incorrectly associated with Department of Anesthesiology, The First Affiliated Hospital of Zhengzhou University, Zhengzhou 450052, Henan, China. This has not been corrected in both the PDF and HTML versions of the article.

Published online: 14 September 2020

(c) Open Access This article is licensed under a Creative Commons Attribution 4.0 International License, which permits use, sharing, adaptation, distribution and reproduction in any medium or format, as long as you give appropriate credit to the original author(s) and the source, provide a link to the Creative Commons license, and indicate if changes were made. The images or other third party material in this article are included in the article's Creative Commons license, unless indicated otherwise in a credit line to the material. If material is not included in the article's Creative Commons license and your intended use is not permitted by statutory regulation or exceeds the permitted use, you will need to obtain permission directly from the copyright holder. To view a copy of this license, visit http://creativecommons.org/licenses/by/4.0/.

(C) The Author(s) 2020 